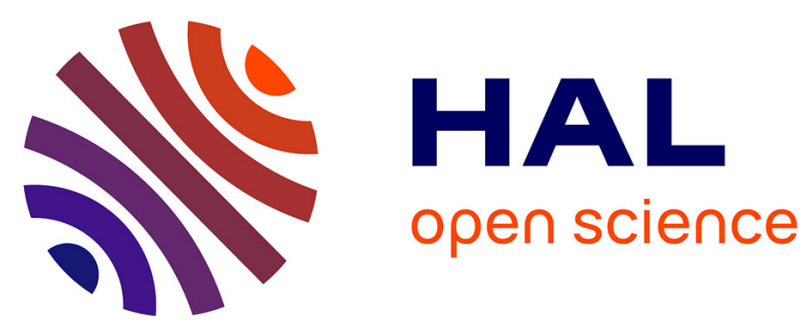

\title{
Improved predictability of the troposphere using stratospheric final warmings
}

Steven C. Hardiman, Neal Butchart, Andrew J. Charlton-Perez, Tiffany A.

Shaw, Hideharu Akiyoshi, Andreas Baumgaertner, Slimane Bekki, Peter

Braesicke, Martyn Chipperfield, Martin Dameris, et al.

\section{To cite this version:}

Steven C. Hardiman, Neal Butchart, Andrew J. Charlton-Perez, Tiffany A. Shaw, Hideharu Akiyoshi, et al.. Improved predictability of the troposphere using stratospheric final warmings. Journal of Geophysical Research: Atmospheres, 2011, 116, pp.D18113. 10.1029/2011JD015914 . hal-00627589

\section{HAL Id: hal-00627589 \\ https://hal.science/hal-00627589}

Submitted on 3 Sep 2020

HAL is a multi-disciplinary open access archive for the deposit and dissemination of scientific research documents, whether they are published or not. The documents may come from teaching and research institutions in France or abroad, or from public or private research centers.
L'archive ouverte pluridisciplinaire HAL, est destinée au dépôt et à la diffusion de documents scientifiques de niveau recherche, publiés ou non, émanant des établissements d'enseignement et de recherche français ou étrangers, des laboratoires publics ou privés. 


\title{
Improved predictability of the troposphere using stratospheric final warmings
}

\author{
Steven C. Hardiman, ${ }^{1}$ Neal Butchart, ${ }^{1}$ Andrew J. Charlton-Perez, ${ }^{2}$ Tiffany A. Shaw, ${ }^{3}$ \\ Hideharu Akiyoshi, ${ }^{4}$ Andreas Baumgaertner, ${ }^{5}$ Slimane Bekki, ${ }^{6}$ Peter Braesicke, ${ }^{7}$ \\ Martyn Chipperfield ${ }^{8}$ Martin Dameris, ${ }^{9}$ Rolando R. Garcia, ${ }^{10}$ Martine Michou, ${ }^{11}$ \\ Steven Pawson, ${ }^{12}$ Eugene Rozanov, ${ }^{13,14}$ and Kiyotaka Shibata ${ }^{15}$ \\ Received 4 March 2011; revised 30 June 2011; accepted 7 July 2011; published 29 September 2011.
}

[1] The final warming of the stratospheric polar vortex at the end of northern hemisphere winter is examined in ECMWF ERA-Interim reanalysis data and an ensemble of chemistry climate models, using 20 years of data from each. In some years the final warming is found to occur first in the mid-stratosphere, and in others to occur first in the upper stratosphere. The strength of the winter stratospheric polar vortex, refraction of planetary waves, and the altitudes at which the planetary waves break in the northern extratropics lead to this difference in the vertical profile of the final warming. Years in which the final warming occurs first in the mid-stratosphere show, on average, a more negative NAO pattern in April mean sea level pressure than years in which the warming occurs first in the upper stratosphere. Thus, in the northern hemisphere, additional predictive skill of tropospheric climate in April can be gained from a knowledge of the vertical profile of the stratospheric final warming.

Citation: Hardiman, S. C., et al. (2011), Improved predictability of the troposphere using stratospheric final warmings, J. Geophys. Res., 116, D18113, doi:10.1029/2011JD015914.

\section{Introduction}

[2] The final warming of the winter stratosphere is associated with the breakdown of the polar vortex. During the

\footnotetext{
${ }^{1}$ Met Office Hadley Centre, Exeter, UK.

${ }^{2}$ Department of Meteorology, University of Reading, Reading, UK.

${ }^{3}$ Department of Applied Physics and Applied Mathematics, Columbia University, New York, USA.

${ }^{4}$ Atmospheric Environment Division, National Institute for Environmental Studies, Tsukuba, Japan.

${ }^{5}$ Max-Planck-Institut für Chemie, Mainz, Germany.

${ }^{6}$ LATMOS-IPSL, UVSQ, UPMC, CNRS/INSU, France.

${ }^{7}$ Chemistry Department, National Centre for Atmospheric Science, University of Cambridge, Cambridge, UK.

${ }^{8}$ School of Earth and Environment, Institute for Climate and Atmospheric Science, University of Leeds, Leeds, UK.

${ }^{9}$ Deutsches Zentrum für Luft und Raumfahrt, Institut für Physik der Atmosphäre, Oberpfaffenhofen, Germany.

${ }^{10}$ Atmospheric Chemistry Division, National Center for Atmospheric Research, Boulder, Colorado, USA.

${ }^{11}$ GAME/CNRM, Météo-France, CNRS, Toulouse, France.

${ }^{12}$ Global Modeling and Assimilation Office, NASA Goddard Space Flight Center, Greenbelt, Maryland, USA.

${ }^{13}$ Physical-Meteorological Observatory Davos/World Radiation Center, Davos, Switzerland.

${ }^{14}$ ETH Zurich, Zurich, Switzerland.

${ }^{15}$ Atmospheric Environment and Applied Meteorology Research Department, Meteorological Research Institute, Tsukuba, Japan.
}

Copyright 2011 by the American Geophysical Union. 0148-0227/11/2011JD015914 final warming, the zonal mean zonal wind in the extratropics undergoes a reversal from a westerly to an easterly direction. The final warming occurs in November/December in the southern hemisphere (SH), and from as early as March to as late as May in the northern hemisphere (NH) [Waugh and Rong, 2002]. As explained below, the timing of the final warming is of considerable interest, both due to its sensitivity to stratospheric ozone concentrations and its potential role in tropospheric predictability.

[3] The final warming is driven partly by the radiative cycle in the stratosphere. The equator-pole temperature gradient caused by shortwave heating and longwave cooling means that the zonal mean flow is westerly in the winter stratosphere and easterly in the summer stratosphere. However, the dynamics of planetary wave propagation and breaking erodes the polar vortex, drives a poleward eddy heat flux, and drives a meridional circulation which leads to downwelling in the extratropics and associated adiabatic warming. These processes cause the final warming to occur earlier in the year than if the warming were solely radiatively driven [Forster et al., 1997]. Indeed, evidence from analysis and reanalysis data suggests the observed final warming is substantially wave driven in both hemispheres [Yamazaki, 1987; Black and McDaniel, 2007b].

[4] In chemistry-climate models, the timing of the simulated final warming is important since a bias in this time is suggestive of a polar temperature/ozone bias (SH only) [Hurwitz et al., 2010]. Further, once the vortex breakdown 

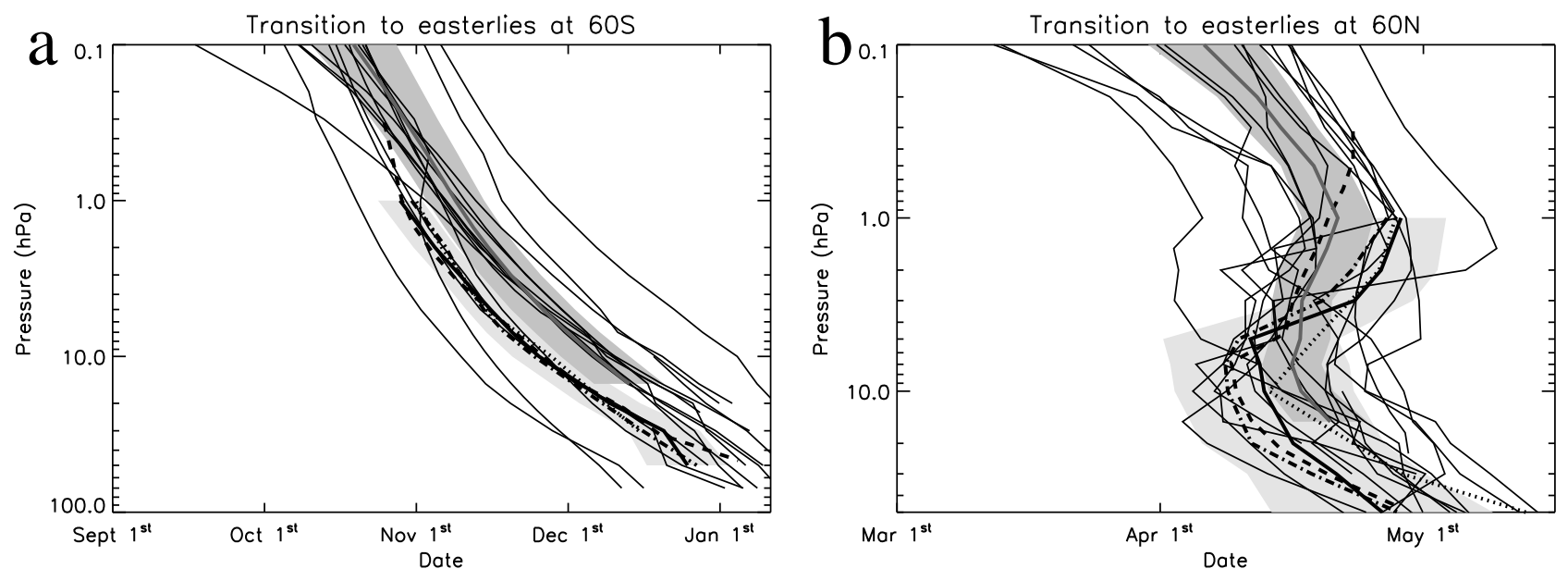

Figure 1. Final transition of zonal mean zonal wind from westerly to easterly at (a) $60^{\circ} \mathrm{S}$ and (b) $60^{\circ} \mathrm{N}$. CCMVal-2 monthly mean model data is used (from 1980-1999), with each model represented by a thin black line and the multimodel mean shown as a thick gray line. The dark gray shading indicates the inter-model standard error, scaled to represent a 95\% confidence interval. ERA-Interim (1989-2009), ERA-40 (1980-2002), and NCEP (1980-1999) reanalysis and UKMO analysis data (1992-2001) are shown as thick black solid, dot-dashed, dotted and dashed lines respectively, with light gray shading indicating the interannual standard deviation in the ERA-Interim data, again scaled to represent a 95\% confidence interval.

has occurred, transport of ozone rich air to polar latitudes can once more occur [Eyring et al., 2006; Yamazaki, 1987].

[5] There are also implications for the high latitude troposphere. During a final warming there is evidence of more consistent stratosphere-troposphere coupling than that due to mid-winter sudden warmings with, for example, influence on the North Atlantic Oscillation (NAO) [Black et al., 2006]. Ayarzagüena and Serrano [2009] note the effect of the $\mathrm{NH}$ final warming time on the Euro-Atlantic area in April, referring to "early" and "late" final warmings [Waugh and Rong, 2002].

[6] In the present study, the final warming time is defined, at each height, as the time when the zonal mean zonal wind, $U$, at $60^{\circ}$ becomes easterly for the final time that spring. Data is used from the European Centre for Medium-Range Weather Forecasts (ECMWF) ERA-Interim [Simmons et al., 2007; Dee et al., 2011] and ERA-40 [Uppala et al., 2005] reanalysis for years 1989-2009 and 1980-2002 respectively, the National Centers for Environmental Prediction/National Center for Atmospheric Research (NCEP) reanalysis [Kalnay et al., 1996] for years 1980-1999, and the UK Met Office (UKMO) stratospheric analysis [Swinbank and O'Neill, 1994] for years 1992-2001. Data is also used from models included in phase 2 of the Chemistry-Climate Model Validation Activity for SPARC (CCMVal-2) taken from years 1980-1999 of the historical simulations [Eyring et al., 2008]. See SPARC CCMVal [2010, chapters 2 and 4] for details of the models and dynamics respectively. The majority of this work uses ERA-Interim data only (six-hourly data was obtained for more accurate calculation of non-linear diagnostics which were then averaged to form daily fields).

[7] In the following sections, the dynamics behind the vertical profile of the final warming in the northern hemisphere shed new light on the interannual variability of the final warming time and its implications for adding skill to the seasonal forecasts of dynamical tropospheric fields in April.

\section{Vertical Profiles of the Final Warming Time}

[8] Figure 1 shows the climatological final warming time at $60^{\circ} \mathrm{S}$ [Butchart et al., 2011; Eyring et al., 2006; Scaife et al., 2002] and $60^{\circ} \mathrm{N}$ [Hardiman et al., 2010] for the CCMVal-2 models, ERA-Interim, ERA-40, and NCEP reanalysis data, and UKMO analysis data (see figure caption for details). In the southern hemisphere (Figure 1a) this final warming time occurs first in the upper stratosphere and then propagates downwards in time. There is good agreement between all reanalyses and the slope of the downward propagation is captured well by the multi-model mean. However, most models show a final warming time which is too late, consistent with there being a cold bias in the winter stratosphere in most models. In the northern hemisphere (Figure 1b) the final warming occurs first in the mid-stratosphere, at around $10 \mathrm{hPa}$. Here the reanalyses show slightly different climatological final warming times, and the interannual variability in the final warming time is somewhat greater than in the southern hemisphere [see Graversen and Christiansen, 2003]. The models also show a greater range of final warming times. Nevertheless the vertical profile of final warming time, occurring first in the mid-stratosphere, is captured well by most models. These profiles are suggestive of a warming in the northern hemisphere which is further from radiative equilibrium, or more dynamically driven, than is the southern hemisphere warming. Consistent with this, the northern hemisphere final warming occurs earlier in the annual cycle than the southern hemisphere warming, even at $1 \mathrm{hPa}$. A warming first in the mid-stratosphere implies that the upper stratosphere is then somewhat decoupled from the middle and lower stratosphere since waves are unable to propagate through the mean easterly flow at $10 \mathrm{hPa}$. Thus the upper 


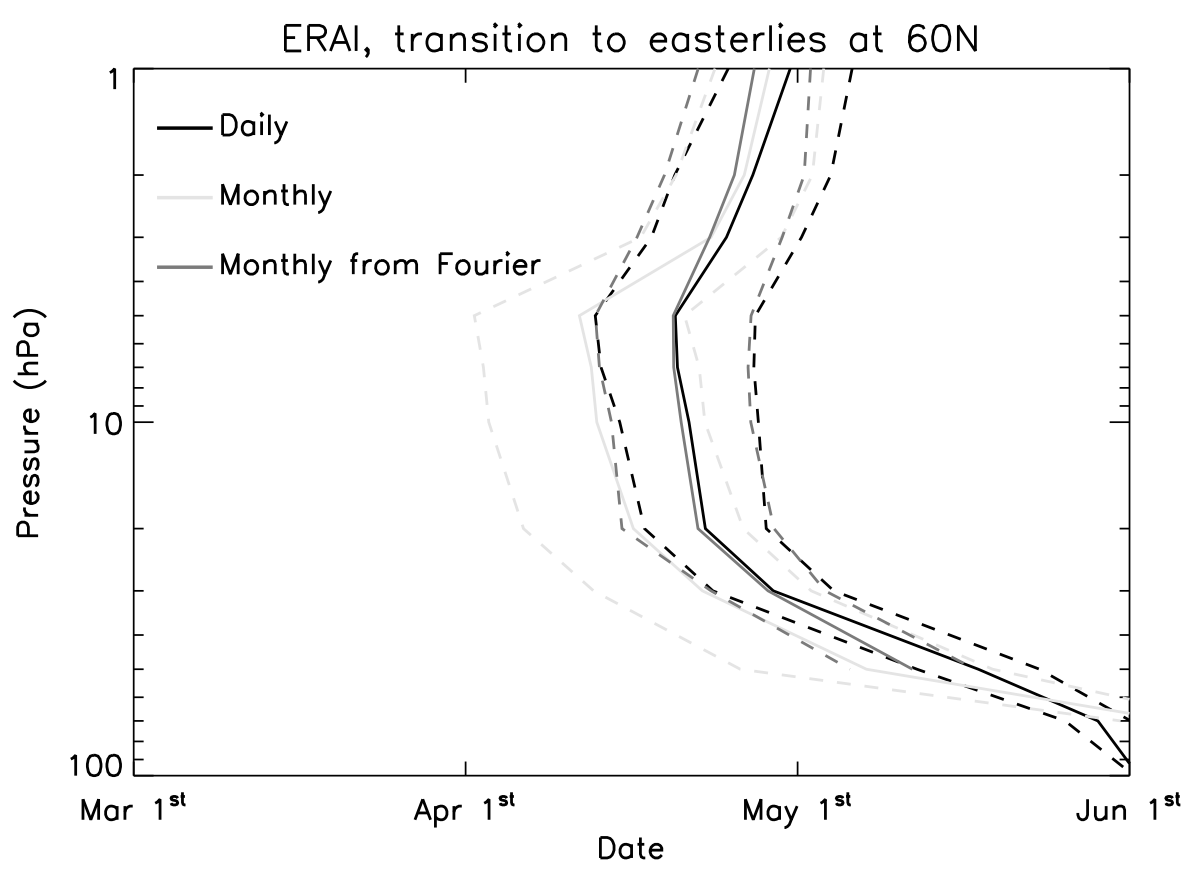

Figure 2. Final transition of zonal mean zonal wind, $U$, from westerly to easterly at $60^{\circ} \mathrm{N}$ in ERA-Interim calculated from: daily data (black lines), linear regression of monthly mean data (light gray lines), and a Fourier fit to the annual cycle in monthly mean data (using the first 6 Fourier components, i.e. up to 5 cycles per year; dark gray lines). Solid lines give final warming date, and dashed lines show interannual standard deviation scaled to represent a $95 \%$ confidence interval.

stratospheric final warming would be expected to proceed on radiative timescales.

[9] In Figure 1, monthly mean data is used, and the final warming date (when $U$ becomes easterly) is calculated using linear interpolation by assuming the monthly mean value represents the value on day 15 of the month. Monthly mean data was shown as sufficient to accurately calculate the southern hemisphere final warming time in the work of Hardiman et al. [2010]. To demonstrate that monthly mean data is also sufficient in the northern hemisphere, Figure 2 shows the northern hemisphere final warming time calculated for ERA-Interim using daily data, linear interpolation of monthly mean data (as in Figure 1), and a Fourier fit to the annual cycle in monthly mean data. Both methods of extracting the final warming date from monthly mean data qualitatively reproduce the vertical profile obtained from the daily data (namely that the warming occurs first in the midstratosphere). Further, the Fourier fit quantitatively agrees with the daily data to well within the $95 \%$ confidence interval, showing that the information required to extract the final warming date is contained within the monthly mean data. Indeed, only up to the semi-annual Fourier component (the second harmonic) needs to be included to accurately obtain the final warming date (not shown). Linear interpolation produces a final warming date that is too early in April in the mid-stratosphere and finds $81 \%$ of winters to be $10 \mathrm{hPa}$-first as opposed to $72 \%$ of winters being $10 \mathrm{hPa}$-first when calculated from daily data. However, using daily data to calculate the final warming date has problems of its own in the northern hemisphere, with eastward winds remaining close to zero for several days before becoming westward or undergoing a short transition back to an eastward direction after the main final warming has occurred (both of these events leading to an earlier final warming date being given by linear interpolation). In the present study the ability to qualitatively reproduce the vertical profile of final warming times is sufficient. For simplicity linear interpolation of monthly mean data is used to obtain the final warming date for CCMVal-2 models, since this only requires data for the late winter and spring months.

[10] Although the climatological final warming dates shown in Figure 1 show a warming occurring first in the midstratosphere, when individual years are considered it is found that the warming may either occur first in the mid-stratosphere (hereafter referred to as a " $10 \mathrm{hPa}$-first year") or it may occur first in the mesosphere and descend in a fashion similar to a southern hemisphere final warming (hereafter referred to as a " $1 \mathrm{hPa}$-first year"). Figure 3 shows the $\mathrm{NH}$ final warming times composited over $10 \mathrm{hPa}$-first years (years in which $U$ $\left(60^{\circ} \mathrm{N}\right)$ becomes easterly at $10 \mathrm{hPa}$ before it becomes easterly at $1 \mathrm{hPa}$; Figure $3 \mathrm{a}$ ) and $1 \mathrm{hPa}$-first years (years in which $U$ $\left(60^{\circ} \mathrm{N}\right)$ becomes easterly at $1 \mathrm{hPa}$ before it becomes easterly at $10 \mathrm{hPa}$; Figure $3 \mathrm{~b}$ ), for ERA-Interim and the CCMVal-2 models. At $0.1 \mathrm{hPa}$ the warming times are similar in both cases - the key difference is whether or not a warming takes place first in the mid-stratosphere. At $10 \mathrm{hPa}$, slightly more than half the models show a final warming time earlier than ERA-Interim in both cases, but in Figure $1 \mathrm{~b}$ the models generally show a later final warming time than ERA-Interim at $10 \mathrm{hPa}$. The likely reason for this is that, in ERA-Interim $81 \%$ of years are $10 \mathrm{hPa}$-first years, whereas only $36 \%$ of all modeled years are $10 \mathrm{hPa}$-first years.

[11] While the distribution of the difference in the final warming time at $10 \mathrm{hPa}$ compared to $1 \mathrm{hPa}$ is not strictly 

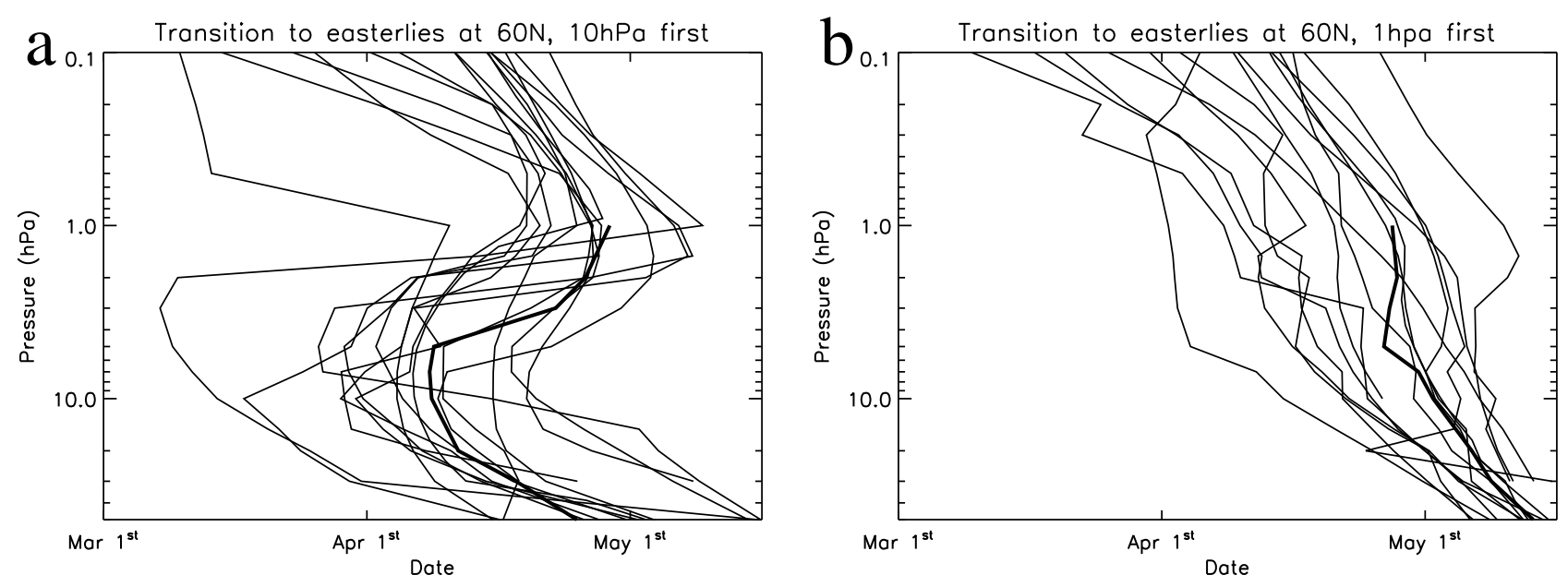

Figure 3. Mean final warming date at $60^{\circ} \mathrm{N}$ composited over (a) $10 \mathrm{hPa}$-first years and (b) $1 \mathrm{hPa}$-first years (defined in text), calculated from CCMVal-2 model data (thin lines) and ERA-Interim (thick line).

bimodal, the behavior of the $10 \mathrm{hPa}$-first and $1 \mathrm{hPa}$-first cases is quite distinct, resulting from qualitatively different behavior in the period prior to the warming. (It is interesting to note that, in ERA-Interim, the final warming in the southern hemisphere is of " $1 \mathrm{hPa}$-first" type in every year except 2002 when the final warming occurs first at around $3 \mathrm{hPa}$. This is the year in which a mid-winter sudden warming was seen in the southern hemisphere. No " $10 \mathrm{hPa}$-first" type final warmings are found in the southern hemisphere in the models.)

\section{Causes of the Different Vertical Profiles}

[12] It might be expected that more dynamically active winters lead to $10 \mathrm{hPa}$-first final warmings, and less dynam- ically active winters to $1 \mathrm{hPa}$-first final warmings. (Here less dynamically active means less wave-mean flow interaction. Dynamical wave coupling will still occur [Perlwitz and Harnik, 2004].) Figure 4 shows that, for ERA-Interim, February mean zonal mean zonal wind, composited over all winters showing a $10 \mathrm{hPa}$-first final warming, is indeed anomalously weak. The anomaly is small since the majority of winters in ERA-Interim show a $10 \mathrm{hPa}$-first final warming (an anomalously strong polar vortex with anomalies of up to $5 \mathrm{~m} \mathrm{~s}^{-1}$ is seen in the $1 \mathrm{hPa}$-first case, not shown). The signal in the tropics, changing sign around $30 \mathrm{hPa}$, suggests possible links to the phase of the Quasi-Biennial Oscillation (QBO) [Baldwin et al., 2001]. However there are many more $10 \mathrm{hPa}-$ first years than $1 \mathrm{hPa}$-first years, so any link to the QBO is likely to be weak and may be the result of randomly selecting

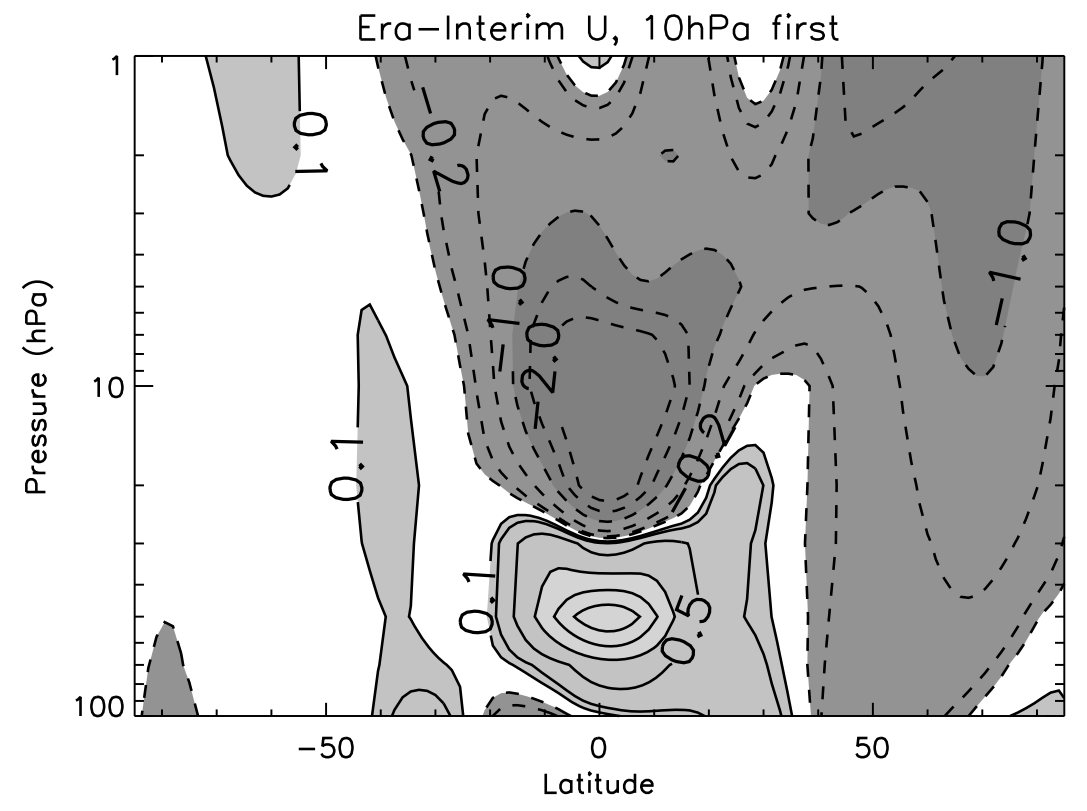

Figure 4. Composite of February mean zonal mean zonal wind anomalies (February mean climatology removed) $\left(\mathrm{m} \mathrm{s}^{-1}\right)$ over winters that go on to show a $10 \mathrm{hPa}$-first final warming, ERA-Interim. Solid contours and light gray shading indicate positive values, dashed contours and dark gray shading indicate negative values. Contour interval is logarithmic. 

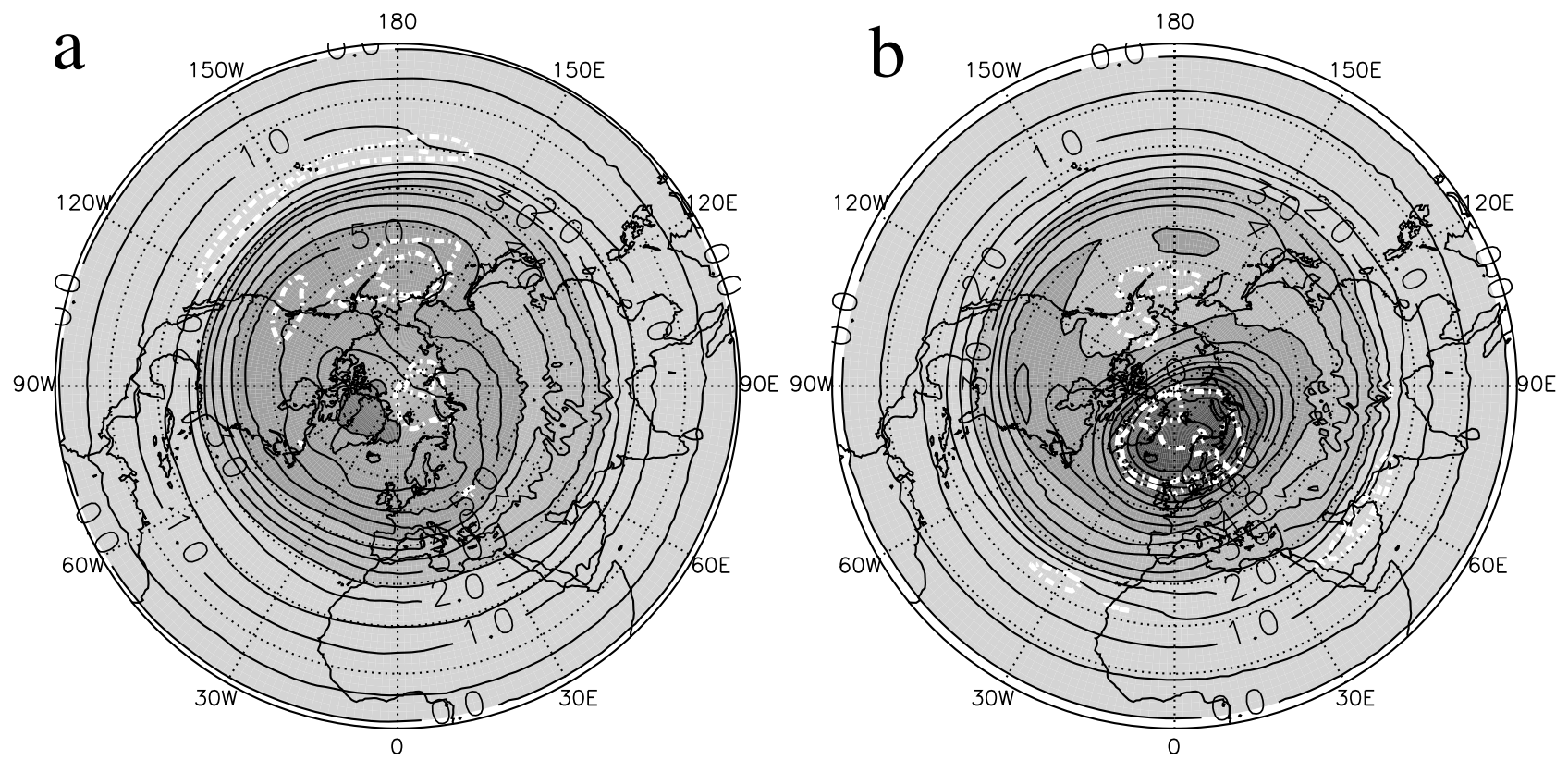

Figure 5. Potential vorticity on $840 \mathrm{~K}$ surface $(\sim 10 \mathrm{hPa})$ averaged in each year over the 20 days before the final warming date and composited over (a) $10 \mathrm{hPa}$-first years and (b) $1 \mathrm{hPa}$-first years, ERA-Interim. Units are $(\mathrm{gH} / \mathrm{p}) 10^{-4} \mathrm{~K} \mathrm{~m}^{-1} \mathrm{~s}^{-1}$, where $\mathrm{g}=9.80665 \mathrm{~m} \mathrm{~s}^{-2}, \mathrm{H}=7000 \mathrm{~m}$, and $\mathrm{p}=1000 \mathrm{hPa}$. White dot-dashed lines show statistical significance, calculated using a T-test, at $90 \%$ and $95 \%$ levels.

winters in a particular phase of the QBO and indeed the signal here would be inconsistent with the Holton-Tan effect [Holton and Tan, 1980].

[13] Further evidence of a weaker polar vortex in $10 \mathrm{hPa}-$ first years is shown in Figure 5. Potential vorticity on the $840 \mathrm{~K}$ isentropic surface $(\sim 10 \mathrm{hPa})$ is averaged in each year over the 20 days before the final warming date at $5 \mathrm{hPa}$ and composited over $10 \mathrm{hPa}$-first years (Figure 5a) and $1 \mathrm{hPa}$-first years (Figure 5b), using daily ERA-Interim data. It can be seen that the averaged polar vortex in $10 \mathrm{hPa}$-first years is weaker with a weaker PV gradient at the vortex edge, char- acteristic of more dynamically active regimes. This difference, calculated here in both composites using the final warming date at $5 \mathrm{hPa}$, is independent of the exact choice of final warming dates (and therefore of the exact height at which the final warming date is defined). In both composites the polar vortex is, characteristically, centered off the pole, toward $45^{\circ} \mathrm{W}$ in the $10 \mathrm{hPa}$-first case and $30^{\circ} \mathrm{E}$ in the $1 \mathrm{hPa}$-first case.

[14] These differences in polar vortex strength and structure lead to differences in planetary wave propagation and breaking over the 20 days before the final warming date
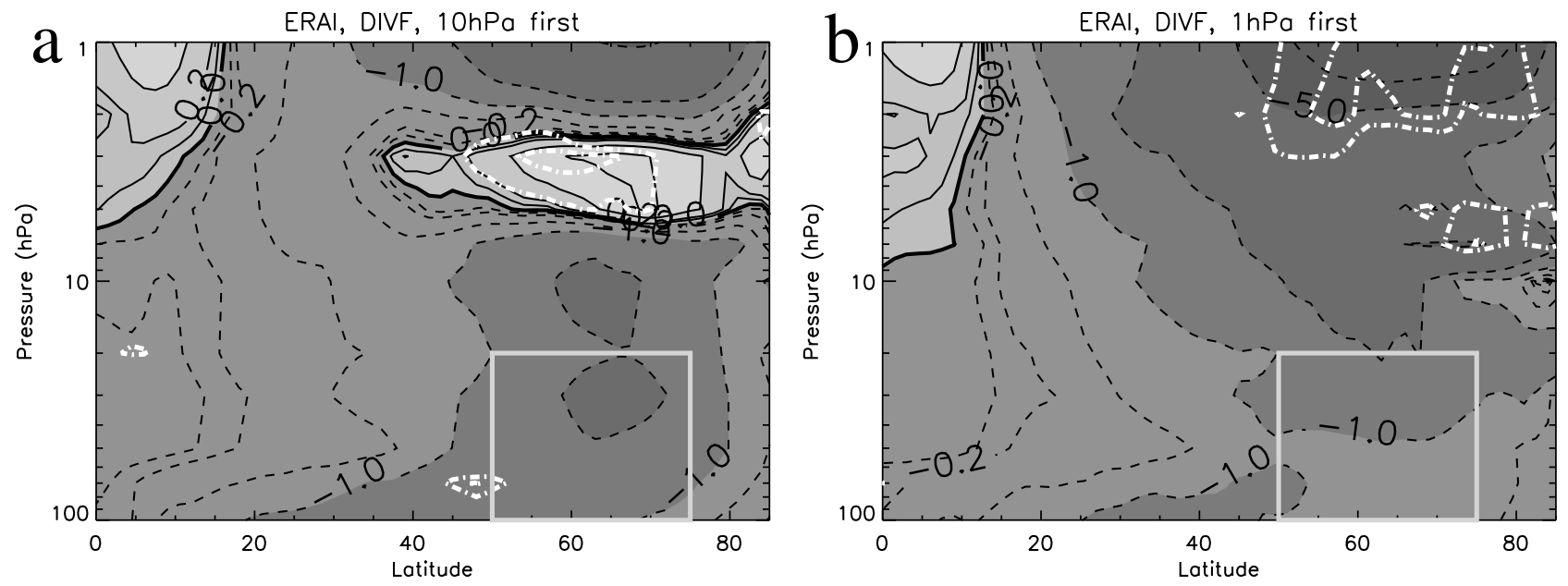

Figure 6. Scaled EP-flux divergence (DIVF) averaged in each year over the 20 days before the final warming date and composited over (a) $10 \mathrm{hPa}$-first years and (b) $1 \mathrm{hPa}$-first years, ERA-Interim. Solid contours and light gray shading indicate positive values, dashed contours and dark gray shading indicate negative values. Contour interval is logarithmic. White dot-dashed lines show statistical significance at $90 \%$ and $95 \%$ levels. 

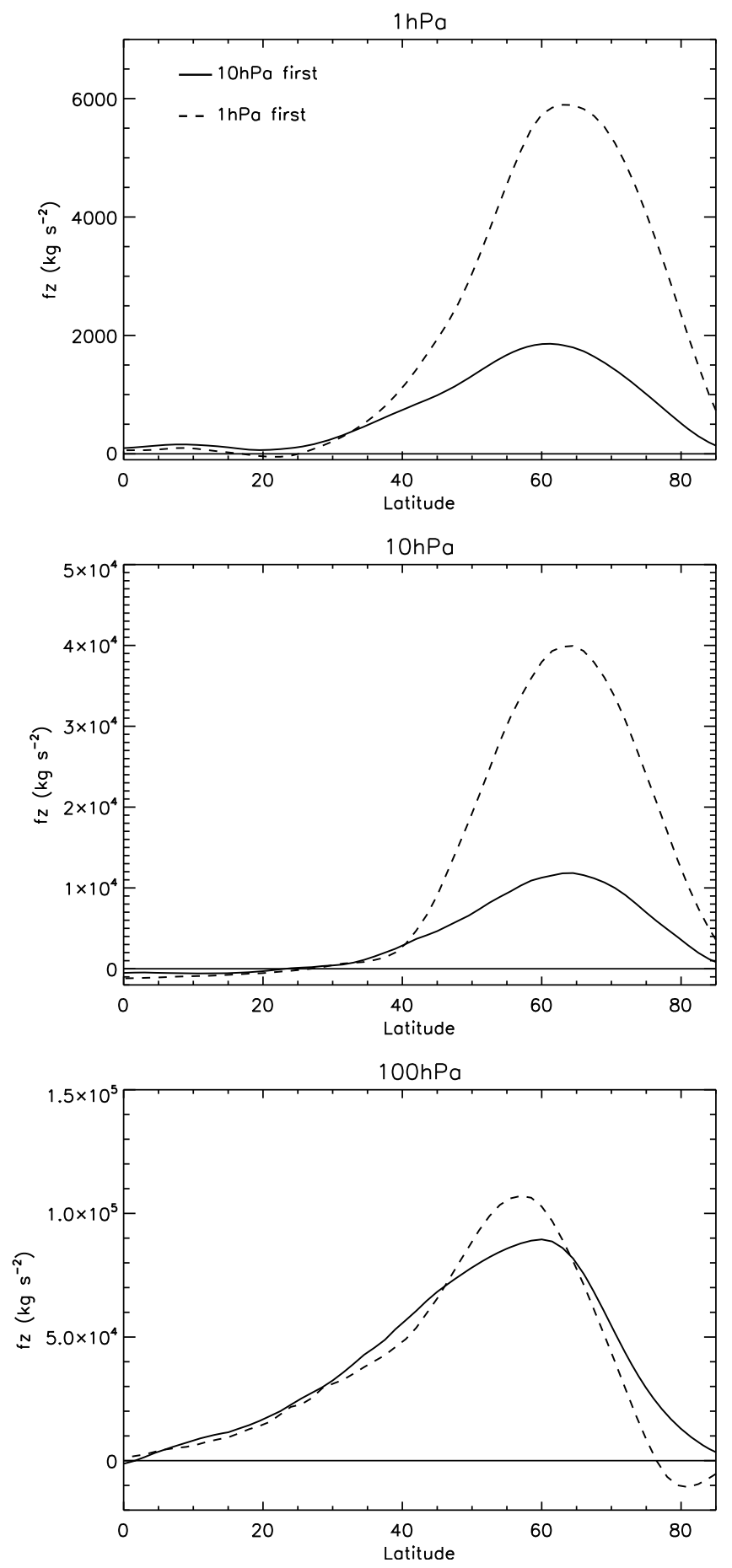

Figure 7. Vertical component of EP-flux $\left(F^{(z)}\right)$ averaged in each year over the 20 days before the final warming date and composited over $10 \mathrm{hPa}$-first years (solid lines) and $1 \mathrm{hPa}-$ first years (dashed lines) at $1 \mathrm{hPa}, 10 \mathrm{hPa}$ and $100 \mathrm{hPa}$, ERA-Interim. Zero line is plotted.

which, as shown below, contribute to the different vertical profiles of final warming.

[15] The forcing on the zonal mean flow by the breaking of planetary waves is given by the Eliassen-Palm flux (hereafter
EP-flux) divergence [Andrews et al., 1987], here scaled to units of zonal acceleration:

$$
\mathrm{DIVF}=\frac{\nabla \cdot \mathbf{F}}{\rho_{0} a \cos \phi}
$$

where $\mathbf{F}$ is the EP flux vector

$$
\begin{gathered}
F^{(\phi)}=\rho_{0} a \cos \phi\left(\bar{u}_{z} \frac{\overline{v^{\prime} \theta^{\prime}}}{\bar{\theta}_{z}}-\overline{v^{\prime} u^{\prime}}\right) \\
F^{(z)}=\rho_{0} a \cos \phi\left\{\left[f-\frac{(\bar{u} \cos \phi)_{\phi}}{a \cos \phi}\right] \frac{\overline{v^{\prime} \theta^{\prime}}}{\bar{\theta}_{z}}-\overline{w^{\prime} u^{\prime}}\right\} .
\end{gathered}
$$

$f$ is the Coriolis parameter, $(u, v, w)$ is three-dimensional velocity in spherical co-ordinates $(\lambda, \phi, z), z$ is $\log$ (pressure) height, $a$ the Earth's radius, and $\rho_{0}(z)$ the density profile of the atmosphere.

[16] Figure 6 shows the scaled EP-flux divergence (DIVF) averaged in each year over the 20 days before the final warming date at $5 \mathrm{hPa}$ and composited over $10 \mathrm{hPa}$-first years and $1 \mathrm{hPa}$-first years as in Figure 5. Below $20 \mathrm{hPa}$ at around $60^{\circ} \mathrm{N}$ (region denoted by gray box in Figure 6) there is greater EP-flux convergence in the $10 \mathrm{hPa}$-first composite, acting to decelerate the zonal mean flow in the lower stratosphere. There is also a region of EP-flux divergence (positive acceleration of the mean flow) around $5 \mathrm{hPa}$ and poleward of $40^{\circ} \mathrm{N}$ in the $10 \mathrm{hPa}$-first composite. This divergence comes from the horizontal component of the EP-flux, and is due to a greater equatorward propagation of planetary waves in the $10 \mathrm{hPa}$-first composite, increasing with decreasing latitude in this region. This structure of EP-flux divergence above EP-flux convergence before a final warming is seen also in the work of Black and McDaniel [2007a]. Planetary waves in the $1 \mathrm{hPa}$-first composite, however, decelerate the mean flow at all heights (poleward of $15^{\circ} \mathrm{N}$ ), more strongly in the upper stratosphere than the lower stratosphere (Figure 6b). The differences between the composites are most apparent poleward of $35^{\circ} \mathrm{N}$. The vertical component of the EP-flux $\left(F^{(z)}\right)$ through $100 \mathrm{hPa}, 10 \mathrm{hPa}$, and $1 \mathrm{hPa}$ surfaces (shown in Figure 7) further demonstrates that, although there is the same planetary wave flux into the stratosphere in both composites, there is less wave flux across the $10 \mathrm{hPa}$ and $1 \mathrm{hPa}$ surfaces in $10 \mathrm{hPa}$-first years than there is in $1 \mathrm{hPa}$-first years. This demonstrates more wave breaking below $10 \mathrm{hPa}$ in the $10 \mathrm{hPa}$-first years (even though the difference below $10 \mathrm{hPa}$ is not as statistically significant as the difference above).

[17] For given values of zonal mean zonal wind, $U$, and zonal mean temperature, $T$, the regions to which planetary waves tend to propagate is given by the wave refractive index $n^{2}$ [Matsuno, 1970] where, following the notation of Simpson et al. [2009]:

$$
n^{2}=\left[\frac{\bar{q}_{\phi}}{a(\bar{u}-c)}-\left(\frac{k}{a \cos \phi}\right)^{2}-\left(\frac{f}{2 N H}\right)^{2}\right] a^{2}
$$

$c$ is zonal phase speed (assumed to be 0 here), $k$ is zonal wavenumber ( $k=1$ here), $N$ the buoyancy frequency, $H$ a 

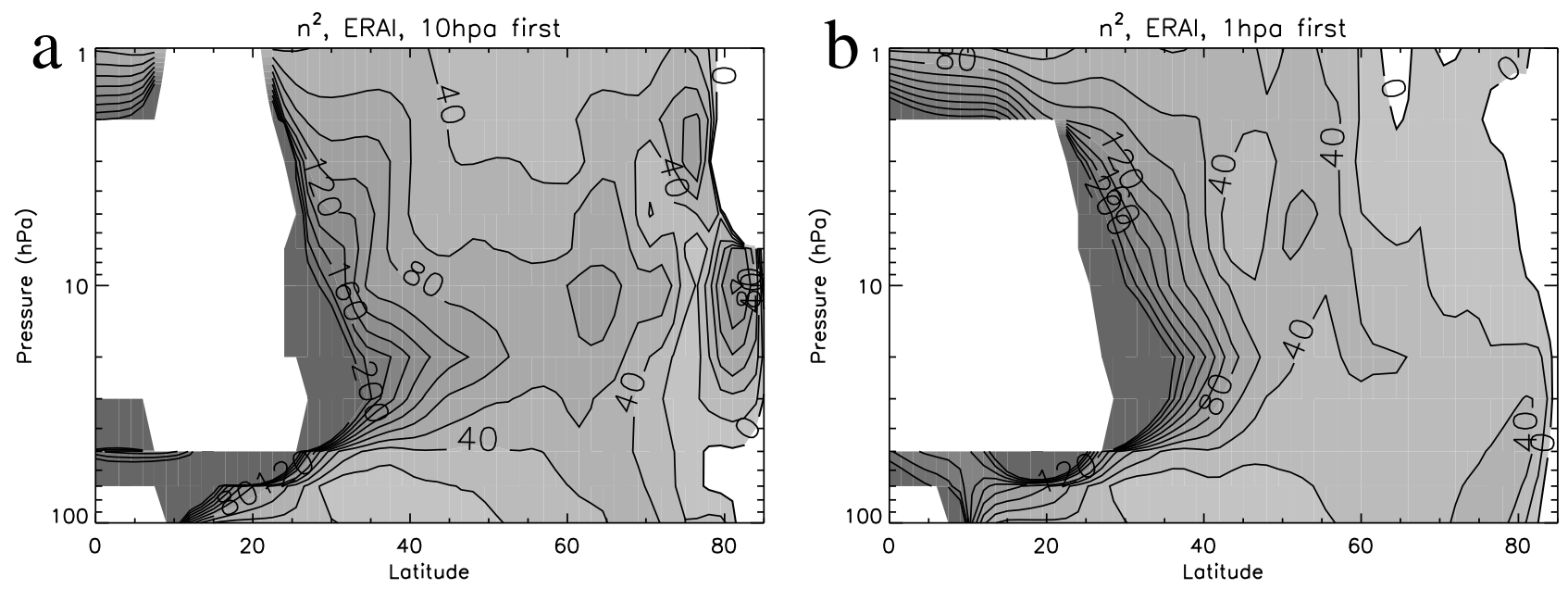

Figure 8. Wave refractive index, $n^{2}\left(\mathrm{~m}^{-2}\right)$, calculated from $U$ and $T$ averaged in each year over the 20 days before the final warming date and composited over (a) $10 \mathrm{hPa}$-first years and (b) $1 \mathrm{hPa}$-first years, ERAInterim. Not plotted for regions where $\bar{u}-c<0$ or $n^{2}<0$.

scale height, and $\bar{q}_{\phi}$ the meridional gradient of the quasigeostrophic potential vorticity [Andrews et al., 1987, equation (3.4.8)].

[18] Planetary waves tend to propagate away from regions of low refractive index, and toward regions of high refractive index. Figure 8 shows the wave refractive index calculated from $U$ and $T$ averaged over the 20 days before the final warming date in each year, and composited as before. The two composites are very similar, except in the region of $10 \mathrm{hPa}$ from around $50^{\circ} \mathrm{N}$ to $70^{\circ} \mathrm{N}$ where the refractive index is twice as large in the $10 \mathrm{hPa}$-first case than in the $1 \mathrm{hPa}$-first case. This local maxima in the $10 \mathrm{hPa}$-first composite suggests a focusing of waves into this region which causes the final warming to occur first in the mid-stratosphere in these years.

[19] To understand further the meridional wave guide which leads to the focusing of planetary waves in the extratropics, Figure 9 shows regions of meridional and vertical wave evanescence following the method of Harnik and Lindzen [2001]. Between $100 \mathrm{hPa}$ and $10 \mathrm{hPa}$ around $70^{\circ} \mathrm{N}$,
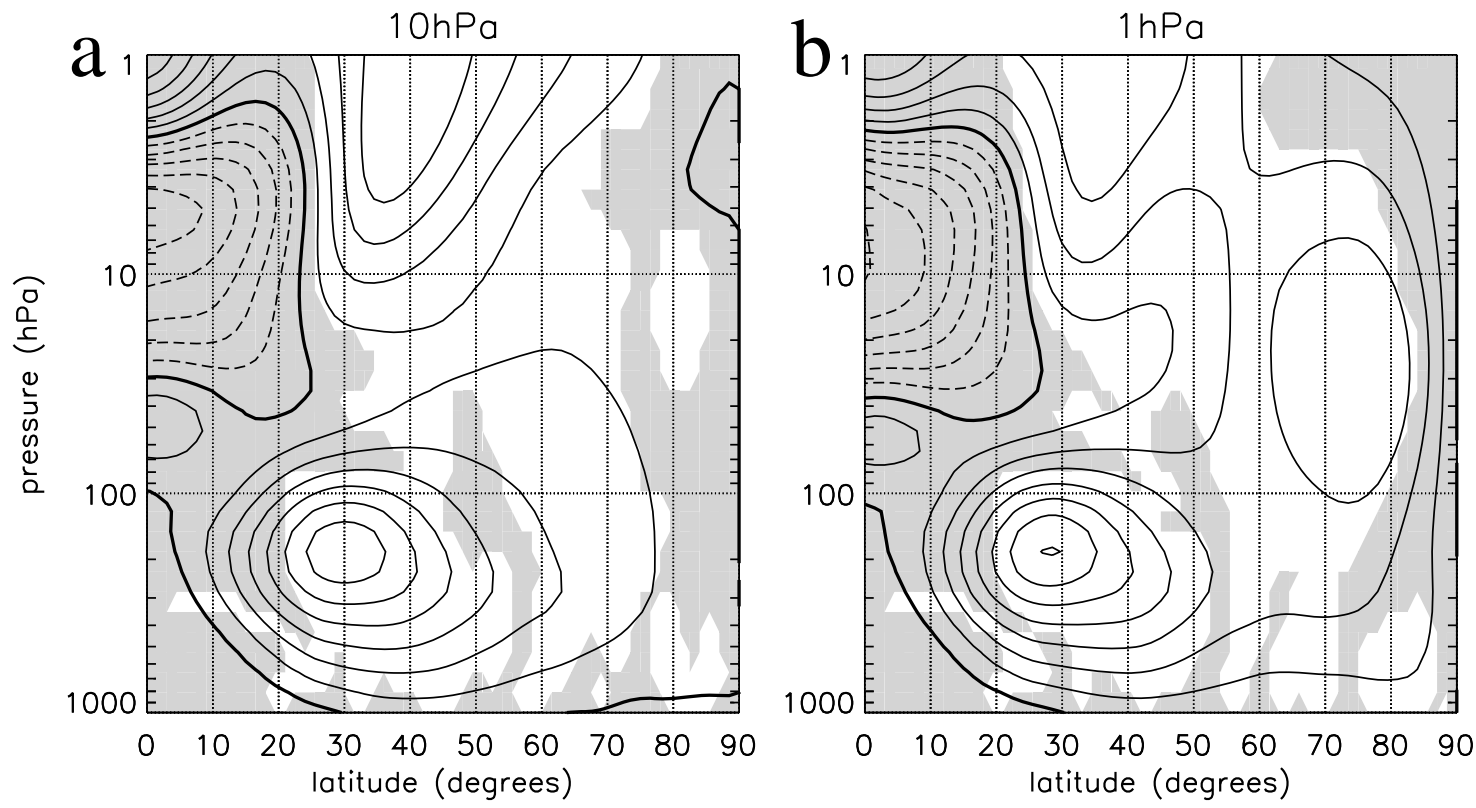

Figure 9. Regions of meridional and vertical wave evanescence (shaded), calculated from $U$ and $T$ averaged in each year over the 20 days before the final warming date and composited over (a) $10 \mathrm{hPa}$-first years and (b) $1 \mathrm{hPa}$-first years, ERA-Interim. Most shading comes from meridional wave evanescence, with shading in the extratropics above $3 \mathrm{hPa}$ in the $1 \mathrm{hPa}$-first case coming from vertical wave evanescence. Contours show positive (solid) and negative (dashed) $U$, with zero contour plotted as thick solid line. Contour interval is $5 \mathrm{~m} \mathrm{~s}^{-1}$. 
a

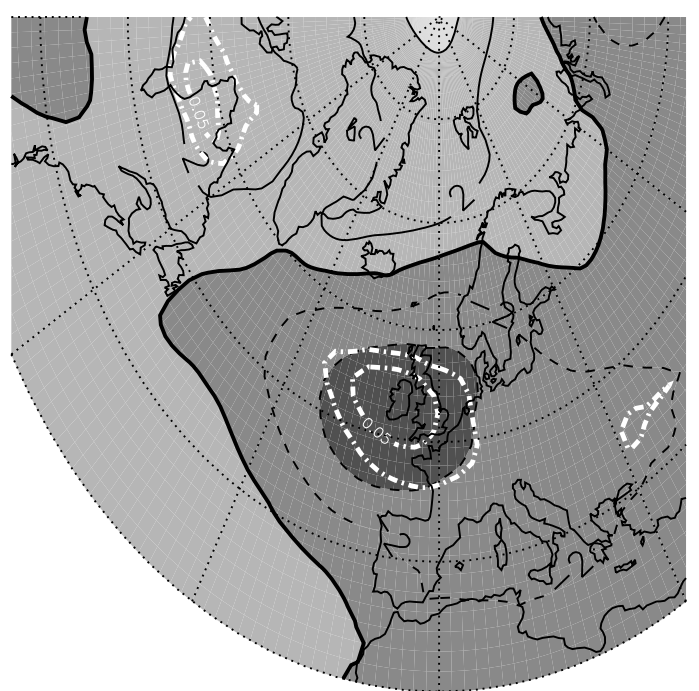

$\mathrm{b}$

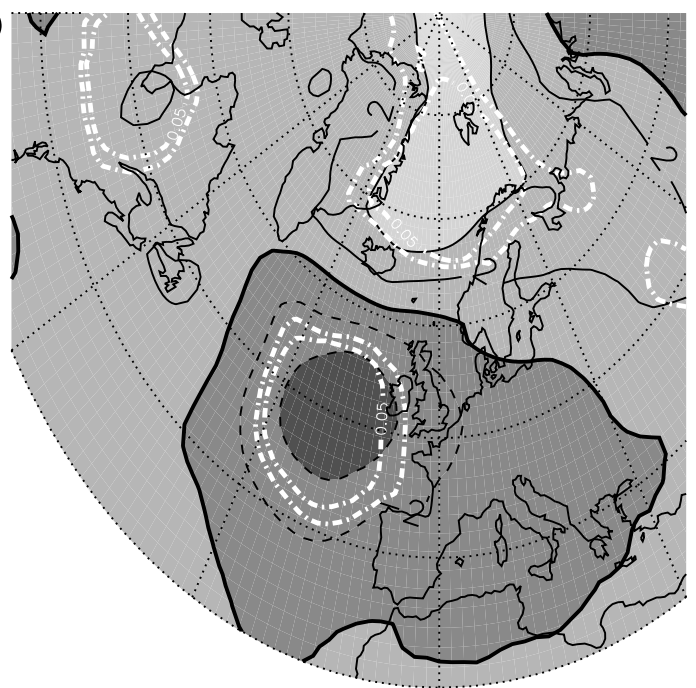

Figure 10. (a) March MSLP $\left(60^{\circ} \mathrm{W}-30^{\circ} \mathrm{E}, 30^{\circ} \mathrm{N}-90^{\circ} \mathrm{N}\right)$, ERA-Interim, difference in composite over years in which the polar vortex is anomalously weak in February and years in which the polar vortex is anomalously strong in February. (b) April MSLP $\left(60^{\circ} \mathrm{W}-30^{\circ} \mathrm{E}, 30^{\circ} \mathrm{N}-90^{\circ} \mathrm{N}\right)$, ERA-Interim, difference in composite over years in which the polar vortex is anomalously weak in March and years in which the polar vortex is anomalously strong in March. White dot-dashed lines show statistical significance at $90 \%$ and $95 \%$ levels (i.e. T-test p-values of 0.1 and 0.05 ). Shading and contour style as before, with zero contour plotted as thick solid line. Contour interval is $2 \mathrm{hPa}$.

$U$ is much weaker in the $10 \mathrm{hPa}$-first composite, with values $<5 \mathrm{~m} \mathrm{~s}^{-1}$, than in the $1 \mathrm{hPa}$-first composite, with values $>15 \mathrm{~m} \mathrm{~s}^{-1}$. Also waves are confined to a region $40^{\circ} \mathrm{N}-70^{\circ} \mathrm{N}$ in the $10 \mathrm{hPa}$-first composite as opposed to being confined to $40^{\circ} \mathrm{N}-80^{\circ} \mathrm{N}$ in the $1 \mathrm{hPa}$-first composite. The result is that, in $10 \mathrm{hPa}$-first years, waves are forced to propagate through a region of very weak zonal wind just below $10 \mathrm{hPa}$ where, for stationary waves, non-linear effects will dominate and wave breaking will likely occur [Andrews et al., 1987, pp. 253-258], leading to a decrease in zonal wind and potential for a positive feedback. Thus planetary waves will likely break lower in $10 \mathrm{hPa}$-first years than in $1 \mathrm{hPa}$-first years, leading to the differences in planetary wave propagation and breaking already seen (Figures 6 and 7), and the different vertical profiles of final warming.

\section{Impact on the Troposphere}

[20] Knowledge of the strength of the stratospheric polar vortex aids prediction of tropospheric fields in the following month [Black et al., 2006]. Defining the strength of the polar vortex in any given month as the value of the monthly mean zonal mean zonal wind at $60^{\circ} \mathrm{N}$ and $10 \mathrm{hPa}$, Figure 10a shows the difference in composites of ERA-Interim March MSLP (Mean Sea Level Pressure) over years in which the polar vortex is anomalously weak (weaker than climatology) in February and years in which the polar vortex is anomalously strong (stronger than climatology) in February $\left(60^{\circ} \mathrm{W}-30^{\circ} \mathrm{E}\right.$, poleward of $30^{\circ} \mathrm{N}$ ), and Figure $10 \mathrm{~b}$ shows the same using April MSLP and March polar vortex strength. Following weak vortex months, MSLP is anomalously high over the pole and anomalously low over much of Europe. (See also the response to weak and strong vortex events shown by Baldwin and Dunkerton [2001] and Baldwin and Thompson
[2009]. These papers emphasize the annular nature of this response, but focus here is on the Atlantic sector where the magnitude of the response is far greater than elsewhere.)

[21] Stratospheric warmings give the potential for more skillful prediction of tropospheric fields since the signals of these stratospheric warmings propagate downwards to the troposphere, influencing tropospheric fields up to a few weeks after the initial warming took place [Baldwin and Dunkerton, 2001]. During a stratospheric warming, the stratosphere and troposphere are coupled more strongly than normal [Black et al., 2006].

[22] One advantage of final warmings over sudden stratospheric warmings (SSWs) is that final warmings are guaranteed to occur at the end of every winter whereas the timing of SSWs is much more difficult to predict, and even whether they occur or not during a given winter is subject to enormous decadal variability [Charlton-Perez et al., 2008]. The average final warming date in the mid-stratosphere is April 15th for $10 \mathrm{hPa}$-first years (calculated using daily data - not shown), and Figures 5 and 6 show a significant difference (at the 95\% confidence level) in dynamical fields over the 20 days leading up to this final warming. To demonstrate the difference in signal of $10 \mathrm{hPa}$-first final warmings and $1 \mathrm{hPa}$-first final warmings on tropospheric fields, Figure 11a shows the difference between April mean MSLP composited over $10 \mathrm{hPa}-$ first years and April mean MSLP composited over $1 \mathrm{hPa}$-first years. The pattern obtained is very similar to that in Figure 10, but the signal is much stronger and is statistically significant at the $95 \%$ level over larger regions (this is in part expected as information from early April is included in Figure 11a). The pattern is similar to a negative NAO pattern [Black et al., 2006], and although it is centered further north $\left(\sim 65^{\circ} \mathrm{N}\right)$ than is the NAO pattern $\left(50-55^{\circ} \mathrm{N}\right)$, the correlation coeffi- 

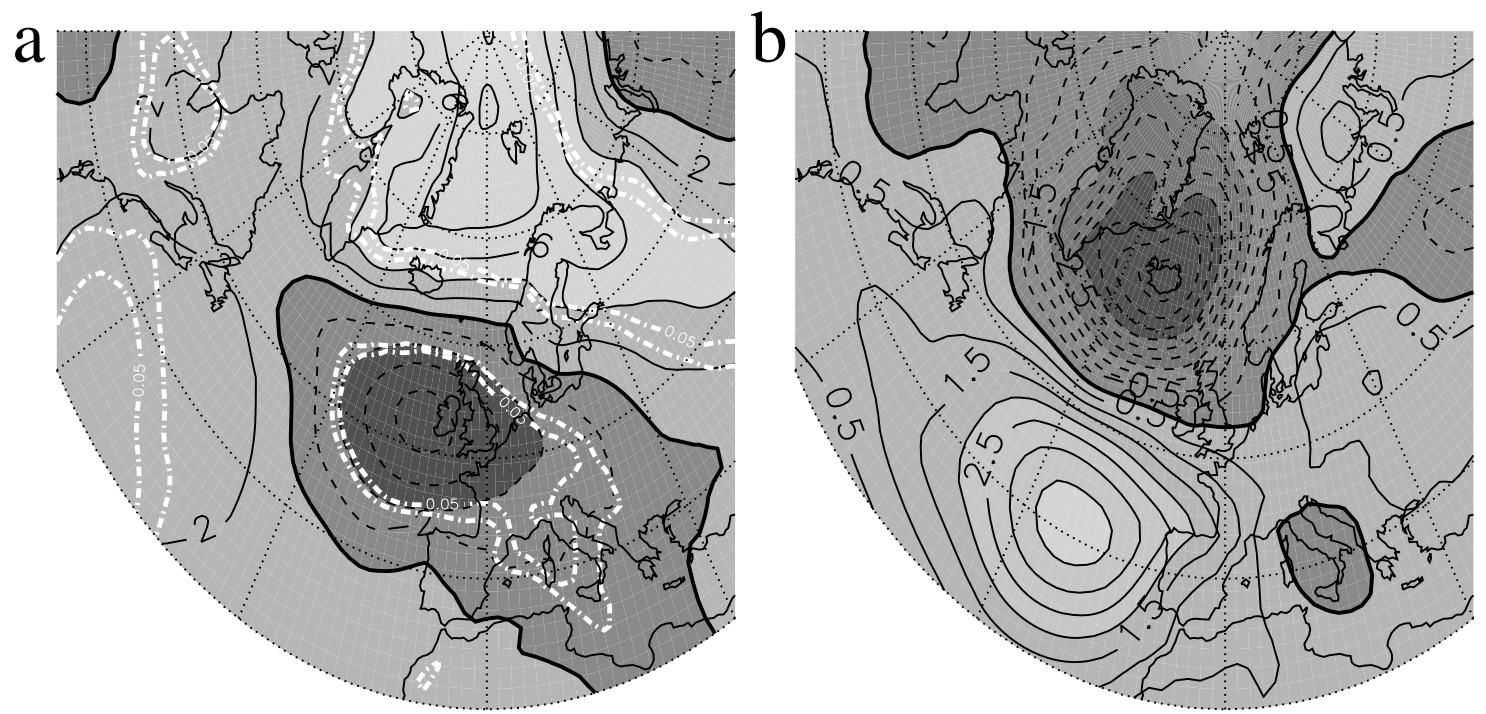

Figure 11. (a) April MSLP $\left(60^{\circ} \mathrm{W}-30^{\circ} \mathrm{E}, 30^{\circ} \mathrm{N}-90^{\circ} \mathrm{N}\right)$, ERA-Interim, difference in composite over $10 \mathrm{hPa}$-first years and composite over $1 \mathrm{hPa}$-first years. Pattern similar to negative NAO pattern. White dot-dashed lines show statistical significance at $90 \%$ and $95 \%$ levels. Contour interval is $2 \mathrm{hPa}$. (b) NAO pattern calculated by regressing ERA-Interim April mean MSLP anomalies on to the April monthly $\mathrm{NAO}$ index. Contour interval is $0.5 \mathrm{hPa}$.

cient with the NAO pattern (Figure $11 \mathrm{~b}$ ) over $60^{\circ} \mathrm{W}-30^{\circ} \mathrm{E}$ and $30^{\circ} \mathrm{N}-90^{\circ} \mathrm{N}$ is -0.52 . The signal in Figure $11 \mathrm{a}$, up to $8 \mathrm{hPa}$ in magnitude over Ireland and Greenland, is about twice the interannual standard deviation in April mean MSLP in these regions (not shown), and so can be considered a significant impact on surface climate. Here the NAO pattern, shown in Figure $11 \mathrm{~b}$, is calculated by regressing ERAInterim April mean sea level pressure anomalies on to the April monthly NAO index (obtained from http://www.cru. uea.ac.uk timo/datapages/naoi.htm).

[23] Christiansen [2005] shows the decorrelation time of the NAO to be around 20 days. Indeed, for ERA-Interim the type of final warming profile (evident from about April 1st, say) correlates no better with the NAO index calculated from a difference in April mean MSLP over Gibraltar and over Reykjavik than does the NAO index calculated from April 1st MSLP (not shown). However, Figure $11 \mathrm{~b}$ shows the NAO pattern to be localized over the Atlantic, and the signal over Europe seen in Figure 11a is not well predicted using April 1st MSLP (not shown). Figure 10 is suggestive of the fact that this signal of same signed MSLP anomalies over the Atlantic and over Europe may instead descend from the polar vortex [see also Ineson and Scaife, 2009, Figure 5]. That the state of the stratosphere on a given date offers more predictive skill than the surface pressure on that date is consistent with the analysis of Baldwin et al. [2003].

\section{Summary and Discussion}

[24] The climatological mean final warming in the northern hemisphere occurs first in the mid-stratosphere at around $10 \mathrm{hPa}$, as seen in both reanalysis data and chemistry-climate model simulations. The final warming occurs around April, earlier in the seasonal cycle than in the southern hemisphere, consistent with the northern hemisphere final warming being more dynamically, rather than radiatively, driven. The information necessary to diagnose the vertical profile of final warming times to well within the $95 \%$ confidence interval is contained in monthly mean data.

[25] On considering individual years it becomes apparent that the climatological final warming profile in the northern hemisphere consists of years in which the final warming occurs first in the mid-stratosphere (termed " $10 \mathrm{hPa}$-first years") and years in which the final warming occurs first in the mesosphere and propagates downwards through the stratosphere as in the southern hemisphere (" $1 \mathrm{hPa}$-first years"). The late bias seen for climatological mean final warming time in models is likely due to the fact that only $36 \%$ of all modeled years are $10 \mathrm{hPa}$-first years, whereas $81 \%$ of years are $10 \mathrm{hPa}$-first years in ERA-Interim. The small fraction of $10 \mathrm{hPa}$-first years in the models is consistent with the finding that models' internal variability is too weak [Butchart et al., 2011]. Indeed, the models' ability to capture the correct final warming date is now arguably worse than their ability to correctly simulate the frequency of sudden stratospheric warmings in the Northern Hemisphere [Butchart et al., 2011].

[26] Years in which the final warming occurs first in the mid-stratosphere show, on average, a weaker polar vortex with more planetary wave breaking below $10 \mathrm{hPa}$ in the days leading up to the final warming than is seen in $1 \mathrm{hPa}$-first years. This wave breaking is caused by the meridional wave guide confining waves to a narrower region and the zonal mean zonal wind being very much weaker in this region than it is in $1 \mathrm{hPa}$-first years. It is unclear what causes these differences in the wave guide and zonal mean zonal wind in the first place.

[27] These different final warming profiles allow potential predictive skill of the surface climate in April. The mean final warming time in the mid-stratosphere in $10 \mathrm{hPa}$-first years 
is April 15th, and significant differences in the dynamical fields are seen between $10 \mathrm{hPa}$-first years and $1 \mathrm{hPa}$-first years in the 20 days leading up to the final warming. On average, $10 \mathrm{hPa}$-first years lead to a more negative NAO pattern in Mean Sea Level Pressure (MSLP) in April than do $1 \mathrm{hPa}$-first years and to anomalously low MSLP over Europe. The difference in MSLP between $10 \mathrm{hPa}$-first and $1 \mathrm{hPa}$-first years is around twice the interannual standard deviation in April mean MSLP in some regions.

[28] Improving the predictability of the NAO may have important implications for seasonal forecasting, as it is known to influence temperature, precipitation and cloudiness over northern Europe through changing the position of the North Atlantic storm track [Folland et al., 2009].

[29] Acknowledgments. The work of $\mathrm{SCH}$ and NB was supported by the Joint DECC/Defra Met Office Hadley Centre Climate Programme (GA01101). The authors would like to thank Steven Rumbold for several useful discussions during the course of this work, and William Seviour for producing the planetary wave flux diagnostics from ERA-Interim data ECMWF ERA-Interim data used in this study have been provided by ECMWF, ERA-40 data used in this study have been obtained from the ECMWF data server, and NCEP Reanalysis data was provided by the NOAA/OAR/ESRL PSD, Boulder, Colorado, USA, from their Web site at http://www.esrl.noaa.gov/psd/. The authors also acknowledge John Austin for providing the GFDL AMTRAC3 model data, the CCMVal Activity for WCRP's SPARC (Stratospheric Processes and their Role in Climate) project for organizing and coordinating the CCM data analysis activity, and the British Atmospheric Data Center (BADC) for collecting and archiving the CCMVal model output. The CCSRNIES simulations in the CCMVal were completed with the super computer at CGER, NIES and supported by the Global Environment Research Fund of the Ministry of the Environment of Japan (A-071).

\section{References}

Andrews, D. G., J. R. Holton, and C. B. Leovy (1987), Middle Atmosphere Dynamics, 489 pp., Academic, San Diego, Calif.

Ayarzagüena, B., and E. Serrano (2009), Monthly characterization of the tropospheric circulation over the Euro-Atlantic area in relation with the timing of stratospheric final warmings, J. Clim., 22, 6313-6324, doi:10.1175/2009JCLI2913.1.

Baldwin, M. P., and T. J. Dunkerton (2001), Stratospheric harbingers of anomalous weather regimes, Science, 294, 581-584.

Baldwin, M. P., and D. W. J. Thompson (2009), A critical comparison of stratosphere-troposphere coupling indices, Q. J. R. Meteorol. Soc., 135, 1661-1672, doi:10.1002/qj.479.

Baldwin, M. P., et al. (2001), The quasi-biennial oscillation, Rev. Geophys., 39, 179-229.

Baldwin, M. P., D. B. Stephenson, D. W. J. Thompson, T. J. Dunkerton, A. J. Charlton, and A. O'Neill (2003), Stratospheric memory and skill of extended-range weather forecasts, Science, 301, 636-640.

Black, R. X., and B. A. McDaniel (2007a), The dynamics of Northern Hemisphere stratospheric final warming events, J. Atmos. Sci., 64, 2932-2946.

Black, R. X., and B. A. McDaniel (2007b), Interannual variability in the Southern Hemisphere circulation organized by stratospheric final warming events, J. Atmos. Sci., 64, 2968-2974.

Black, R. X., B. A. McDaniel, and W. A. Robinson (2006), Stratospheretroposphere coupling during spring onset, J. Clim., 19, 4891-4901.

Butchart, N., et al. (2011), Multimodel climate and variability of the stratosphere, J. Geophys. Res., 116, D05102, doi:10.1029/2010JD014995.

Charlton-Perez, A. J., L. M. Polvani, J. Austin, and F. Li (2008), The frequency and dynamics of stratospheric sudden warmings in the $21 \mathrm{st}$ century, J. Geophys. Res., 113, D16116, doi:10.1029/2007JD009571.

Christiansen, B. (2005), Downward propagation and statistical forecast of the near-surface weather, J. Geophys. Res., 110, D14104, doi:10.1029/ 2004JD005431.

Dee, D. P., et al. (2011), The ERA-Interim reanalysis: Configuration and performance of the data assimilation system, Q. J. R. Meteorol. Soc., 137, 553--597, doi:10.1002/qj.828.

Eyring, V., et al. (2006), Assessment of temperature, trace species, and ozone in chemistry-climate model simulations of the recent past, J. Geophys. Res., 111, D22308, doi:10.1029/2006JD007327.
Eyring, V., M. P. Chipperfield, M. A. Giorgetta, D. E. Kinnison, E. Manzini, K. Matthes, P. A. Newman, S. Pawson, T. G. Shepherd, and D. W. Waugh (2008), Overview of the New CCMVal reference and sensitivity simulations in support of upcoming ozone and climate assessments and the planned SPARC CCMVal, SPARC Newsl., 30, 20-26.

Folland, C. K., J. Knight, H. W. Linderholm, D. Fereday, S. Ineson, and J. W. Hurrell (2009), The summer North Atlantic Oscillation: Past, present, and future, J. Clim., 22, 1082-1103.

Forster, P. M., R. S. Freckleton, and K. P. Shine (1997), On aspects of the concept of radiative forcing, Clim. Dyn., 13, 547-560.

Graversen, R. G., and B. Christiansen (2003), Downward propagation from the stratosphere to the troposphere: A comparison of the two hemispheres, J. Geophys. Res., 108(D24), 4780, doi:10.1029/2003JD004077.

Hardiman, S. C., N. Butchart, S. M. Osprey, L. J. Gray, A. C. Bushell, and T. J. Hinton (2010), The climatology of the middle atmosphere in a vertically extended version of the Met Office's climate model, Part I: Mean state, J. Atmos. Sci., 67, 1509-1525, doi:10.1175/2009JAS3337.1.

Harnik, N., and R. S. Lindzen (2001), The effect of reflecting surfaces on the vertical structure and variability of stratospheric planetary waves, J. Atmos. Sci., 58, 2872-2894.

Holton, J. R., and H.-C. Tan (1980), The influence of the equatorial quasibiennial oscillation on the global circulation at $50 \mathrm{mb}$, J. Atmos. Sci., 37 , 2200-2208, doi:10.1175/1520-0469(1980)037<2200:TIOTEQ>2.0. $\mathrm{CO} ; 2$.

Hurwitz, M. M., P. A. Newman, F. Li, L. D. Oman, O. Morgenstern, P. Braesicke, and J. A. Pyle (2010), Assessment of the breakup of the Antarctic polar vortex in two new chemistry-climate models, J. Geophys. Res., 115, D07105, doi:10.1029/2009JD012788.

Ineson, S., and A. A. Scaife (2009), The role of the stratosphere in the European climate response to El Niño, Nat. Geosci., 2, 32-36, doi:10.1038/ngeo381.

Kalnay, E., et al. (1996), The NCEP/NCAR 40-year reanalysis project, Bull. Am. Meteorol. Soc., 77, 437-471.

Matsuno, T. (1970), Vertical propagation of stationary planetary waves in the winter Northern Hemisphere, J. Atmos. Sci., 27, 871-883.

Perlwitz, J., and N. Harnik (2004), Downward coupling between the stratosphere and troposphere: The relative roles of wave and zonal mean processes, J. Clim., 17, 4902-4909, doi:10.1175/JCLI-3247.1.

Scaife, A. A., N. Butchart, C. D. Warner, and R. Swinbank (2002), Impact of a spectral gravity wave parametrization on the stratosphere in the Met Office Unified Model, J. Atmos. Sci., 59, 1473-1489.

Simmons, A., S. Uppala, D. Dee, and S. Kobayashi (2007), ERA-Interim: New ECMWF reanalysis products from 1989 onwards, ECMWF Newsl. 110, 25-35.

Simpson, I. R., M. Blackburn, and J. D. Haigh (2009), The role of eddies in driving the tropospheric response to stratospheric heating perturbations, J. Atmos. Sci., 66, 1347-1365, doi:10.1175/2008JAS2758.1.

SPARC CCMVal (2010), SPARC Report on the Evaluation of ChemistryClimate Models, edited by V. Eyring, T. G. Shepherd, and D. W. Waugh, SPARC Rep. 5, WCRP-132, WMO/TD 1526, World Clim. Res. Program, Toronto, Ont., Canada.

Swinbank, R., and A. O'Neill (1994), A stratosphere-troposphere data assimilation system, Mon. Weather Rev., 122, 686-702.

Uppala, S. M., et al. (2005), The ERA-40 re-analysis, Q. J. R. Meteorol. Soc., 131, 2961-3012, doi:10.1256/qj.04.176.

Waugh, D. W., and P.-P. Rong (2002), Interannual variability in the decay of lower stratospheric Arctic vortices, J. Meteorol. Soc. Jpn., 80, 997-1012.

Yamazaki, K. (1987), Observations of the stratospheric final warmings in the two hemispheres, J. Meteorol. Soc. Jpn., 65, 51-66.

H. Akiyoshi, Atmospheric Environment Division, National Institute for Environmental Studies, 16-2 Onogawa, Tsukuba, Ibaraki 305-8506, Japan. A. Baumgaertner, Max-Planck-Institut für Chemie, D-55128 Mainz, Germany.

S. Bekki, LATMOS-IPSL, UVSQ, UPMC, CNRS/INSU, 4, place Jussieu, Boite 102-T45-E3, Tour 45-46, E3, F-75252 Paris CEDEX 05, France.

P. Braesicke, Chemistry Department, National Centre for Atmospheric Science, University of Cambridge, Lensfield Road, Cambridge CB2 $1 \mathrm{EW}, \mathrm{UK}$.

N. Butchart and S. C. Hardiman, Met Office Hadley Centre, Exeter EX1 3PB, UK. (steven.hardiman@metoffice.gov.uk)

A. J. Charlton-Perez, Department of Meteorology, University of Reading, Reading RG6 6BB, UK.

M. Chipperfield, School of Earth and Environment, Institute for Climate and Atmospheric Science, University of Leeds, Leeds LS2 9JT, UK. 
M. Dameris, Deutsches Zentrum für Luft und Raumfahrt, Institut für Physik der Atmosphäre, D-82234 Oberpfaffenhofen, Wessling, Bavaria, Germany.

R. R. Garcia, Atmospheric Chemistry Division, National Center for Atmospheric Research, PO Box 3000, Boulder, CO 80307, USA.

M. Michou, GAME/CNRM, Météo-France, CNRS, F-31057 Toulouse, France.

S. Pawson, Global Modeling and Assimilation Office, NASA Goddard Space Flight Center, Greenbelt, MD 20771, USA.
E. Rozanov, Physical-Meteorological Observatory Davos/World Radiation Center, Dorfstrasse 33, CH-7260 Davos Dorf, Switzerland.

T. A. Shaw, Department of Applied Physics and Applied Mathematics, Columbia University, 500 W. 120th St., New York, NY 10025, USA.

K. Shibata, Atmospheric Environment and Applied Meteorology Research Department, Meteorological Research Institute, 1-1 Nagamine, Tsukuba, Ibaraki 305-0052, Japan. 